\section{An empirical research on the possibilities of young people to make decision supporting the glass cliff phenomenon}

\section{Gençlerin, cam uçurum olgusunu destekleyici karar verme olasılıklarına yönelik bir ampirik araştırma}

\author{
Süreyya Ece ${ }^{1}$
}

\begin{abstract}
Due to gender roles, it is not appropriate for women to be in the business world. However, this situation has changed over time due to the increase in the education level of women, the increase in the economic needs of the family, etc.

Women tried to take their place in the business world as low-level employees. Later, they made great efforts and gained qualifications that could reach the executive level. However, since the manager profession is perceived as a male profession, the view that women cannot be an administrator has prevailed, and as a result, it becomes difficult for women to become managers under normal conditions. on the other hands in cases of crisis, women were promoted as managers, and in this manner, it was aimed the responsibility of a possible failure was attributed to the women manager. This situation, which has worn out female managers, has been named as the glass cliff in the literature.

In this study, it was aimed to determine the factors affecting the possibility of young people to support the glass cliff in the future. In this context, students who are studying at Şırnak University were included in the research and asked whether they should bring a male or female manager to an enterprise that has economic problems. Decisions that favor
\end{abstract}

\section{Özet}

Toplumsal cinsiyet rolleri nedeniyle kadınların iş dünyasında yer alması uygun görülmemiştir. Ancak bu durum kadınların eğitim düzeyinin yükselmesi, ailenin ekonomik ihtiyaçlarının artması vb. gibi nedenlerle zaman içerisinde değişmiştir.

Kadınlar iş dünyasında alt düzey çalışan olarak kendisine yer edinmeye çalışmıstır. Daha sonra yoğun çaba sarf ederek yönetici düzeyine gelebilecek nitelikler kazanmıstur. Ancak yöneticilik, erkek mesleği olarak algilandığından kadınların yöneticilik yapamayacağı görüşü hâkim olmuş, bunun sonucunda kadınların normal koşullarda yönetici olması zorlaşmıştur. Kriz durumlarında ise kadınlar yönetici yapılmış ve böylece olası bir başarısızlığın sorumluğunun kadın yöneticiye yüklenilmesi amaçlanmıştır. Kadın yöneticileri yıpratan bu durum literatürde cam uçurum olarak adlandırılmıştır.

$\mathrm{Bu}$ çalışmada ileride iş yaşamında yer alacak gençlerin cam uçurumu destekleme olasillkları üzerinde etkili olan faktörleri belirlemek amaçlanmışır. $\mathrm{Bu}$ kapsamda Şırnak Üniversitesi’nde öğrenim gören öğrenciler araştırmaya dahil edilmiş ve öğrencilere ekonomik sorunlar yaşayan bir işletmenin başına kadın mi yoksa erkek yönetici mi getirilmesi gerektiği sorulmuştur. Kadın yöneticileri tercih eden kararlar cam uçurumu destekleyici bir karar olup, bu karar üzerinde cinsiyet, yaş ve yönetici

\footnotetext{
${ }^{1}$ Dr. Öğr. Üyesi, Şırnak Üniversitesi, İ̈BF, İşletme, sureyyaece@yahoo.com (iD 0000-0002-2110-8091
} 
Ece, S. (2020). Gençlerin, cam uçurum olgusunu destekleyici karar verme olasılıklarına yönelik bir ampirik araştırma. Journal of Human Sciences, 17(1), 304-314. doi:10.14687/jhs.v17i1.5943

women managers are a supportive decision on the glass cliff, and the effect of gender, age and preferences regarding executive position on this decision has been examined. Logistic regression analysis was carried out to determine the decision-making possibilities to support the glass cliff. As a result of the analysis, it has been determined that women and participants who want to be senior managers are more likely to make decisions in the direction of supporting the glass cliff than men and those who want to be lower-middle managers. It was determined that the age factor had no significant effect. The results of the study are thought to give an idea of the possible future reflection of the glass cliff phenomenon.

Keywords: Glass cliff; gender; possibility; senior management; logistic regression.

(Extended English summary is at the end of this document)

\section{Giriş}

Toplumsal cinsiyete dayalı rol dağılımında kadınlara evleri içindeki temizlik, yemek gibi ihtiyaçları karşılama görevi yüklenirken, erkeklere de bir işyerinde çalışarak ya da kendi iş yerini açarak ailenin ekonomik ihtiyaçlarını karşılama görevi verilmiştir. Kadınların, iş yaşamında yer almak istemesi, toplumsal rol dağılımına aykırı bulunmuş ve bu nedenle iş yaşamına atılmak isteyen kadınlar engellerle karşılaşmıştır. Engelleri aşarak iş yaşamına girmeyi başaran kadınlar arasında yönetici pozisyonuna gelmek isteyenler bu sefer de cam tavan, cam uçurum, cam duvar, cam asansör, tokenizm gibi sorunlarla karşılaşmıştur.

Bu çalışmada akademik açıdan cam tavan kadar ilgi görmemiş, ancak en az cam tavan kadar kadın yöneticileri yıpratan bir durum olan cam uçurum olgusu ele alınmıştır. Günümüzde büyük işletmelerde bile uygulanabildiği görülen cam uçurum olgusunun gençler tarafindan nasıl değerlendirildiği, başka bir ifadeyle cam uçurum olgusunu destekleyen karar verme olasıllkları incelenmiştir.

\section{Cam Uçurum Olgusu}

Cam uçurum, bir kurum içerisindeki riskli konumlara kadın çalışanların erkek çalışanlara oranla daha çok görevlendirilmesi eğilimine işaret etmektedir (Ryan vd., 2016). Cam uçurum olgusu, kadın çalışanların, kurumda yüksek başarısızlık riski olan yöneticilik pozisyonlarına getirilmesini ifade etmektedir. Burada amaç söz konusu görevlerde karşılaşılan başarısızlığın, o göreve getirilen kadın yöneticiye yüklenmesidir (Yıldız vd., 2016). Başka bir tanıma göre cam uçurum, bir çalışanın bir kurum içerisinde daha yüksek seviyelere doğru yükselmesini sağlayan baskı ve firsatlardır (Macarie \& Moldovan, 2012). Cam uçurum olgusunda kadınların, bir işletmede terfi edildikleri pretijli görevin riskli bir pozisyon olduğu öne dürülmüştür (Mulcahy \& Linehan, 2014). İssletmenin zarar etmesi söz konusu olduğunda kadın çalışanlar, olumsuz sonuç riskindeki artışla bağlantılı olarak yöneticilik pozisyonuna tercihli olarak yerleştirilebilirler (Ryan \& Haslam, 2005). Kurumun başarısızlı̆̆ından mevcut yönetim sorumlu tutulduğu durumlarda yönetici değişikliğine gidildiği takdirde kadınların yönetici olarak seçilme eğiliminin yüksek olduğu ileri sürülmüştür (Kulich vd., 
Ece, S. (2020). Gençlerin, cam uçurum olgusunu destekleyici karar verme olasılıklarına yönelik bir ampirik araştırma. Journal of Human Sciences, 17(1), 304-314. doi:10.14687/jhs.v17i1.5943

2015). Cam uçurumun ortaya çıkması için zemin hazırlayan faktörler olarak seçim eğilimleri, stereotipler, örgütsel değişim ihtiyacı ve kadınların tercihleri gösterilmiştir (Ryan vd., 2016). Cam uçurum, aşağıdaki şekilde sembolize edilmiştir:

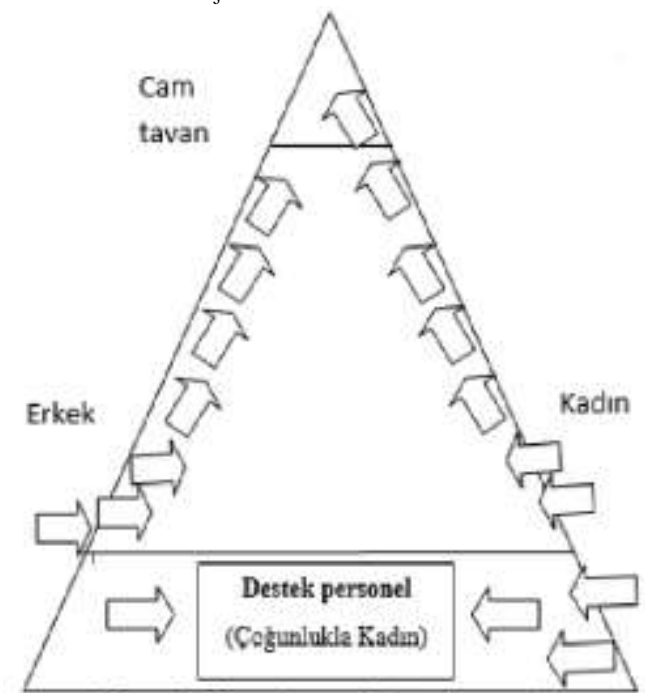

Şekil 1. Cam Uçurum

Kaynak: Y1ldız vd., 2016

Cam uçurumun söz konusu olduğu işletmelerde, erkek çalışanlar, normal koşullarda kadın çalışanlarla yöneticilik pozisyonu arasında yer alan cam tavanın ötesine geçmezken, kadın çalışanlar cam tavanın ötesinde yer alan görevlere geçebilmektedir (bkz Şekil 1). Erkek çalışanlar bu görevleri riskli bulduğundan bu görevleri alma konusunda isteksiz davranmakta, üst düzey yöneticiler de kadın çalışanlara bu görevleri verme eğilimi göstermektedirler. Çünkü üst düzey yöneticiler tarafindan görevdeki risk nedeniyle görevi kim üstlenirse üstlensin başarısız olma olasıllŭı yüksek görülmekte, bu başarısızlığın faturasının da erkek çalışana değil, kadın çalışana kesilmesi planlanmaktadır. Başka bir ifadeyle olası başarısızlık işin doğasından, içinde bulunulan koşullardan vb. gibi kontrol edilemeyen faktörlerden kaynaklansa bile o göreve getirilen kadın yönetici bu durumdan sorumlu tutulur. Kadın çalışanı söz konusu göreve getiren üst düzey erkek yöneticiler, görev başarısız olduğu takdirde "kadınlar yöneticilik yapamaz" şeklindeki cinsiyetçi argümanlarını doğruladıklarını iddia eder ve paydaşlarına karşı başarısızlığın nedenine yönelik sözde bu şekilde bir savunma mekanizması geliştirirler (Ece, 2019).

Özellikle büyük işletmelerde işletme yöneticiliği açısından önemli bir durum olmasına rağmen cam uçurum olgusuna yönelik literatürde az sayıda çalışmaya rastlanmıştır. Bazı çalışmalarda, işletmenin performansının kötü olduğu durumlarda, işletmenin başına kadın yönetici seçilme oranı, erkek yönetici seçilme oranından yüksek çıkmıştır (Haslam \& Ryan, 2008; Smith \& Monaghan, 2013).

Almanya'da yapılan bir araştırmada ise işletmelerin durumu kötüye gittiğinde yönetim kuruluna kadın yöneticinin atanacağının duyurulmasının hissedarlar üzerinde olumlu bir etki yarattı̆̆1 belirlenmiştir. Başka bir ifadeyle işletmenin performansı düştüğünde hissedarlar kadın yöneticilerin işletme üzerinde söz sahibi olmasını beklemektedir (Bechtoldt vd., 2018). Başka bir araştırmada da düşük riskli durumlarda erkek ve kadın yöneticilerin seçilme olasıllğı eşit iken, yüksek riskli durumlarda kadınların yönetici olarak seçilme olasıllğı daha yüksek çıkmıştır (Ashby vd., 2006). İsviçre'deki bir çalışma sonucunda da işletme başarısız olduğunda bir kadının o işletmede lider olma olasıllğının, aynı niteliklere sahip bir erkek çalışana göre daha yüksek olduğu belirlenmiştir (Kulich vd., 2015). İsveç'te yapılan bir araşturma İsveç'te yükseköğretim kurumlarında cam uçurum olgusunun olduğunu göstermiştir (Peterson, 2015). 
Ece, S. (2020). Gençlerin, cam uçurum olgusunu destekleyici karar verme olasıllklarına yönelik bir ampirik araştırma. Journal of Human Sciences, 17(1), 304-314. doi:10.14687/jhs.v17i1.5943

Cam uçurumu ortaya çıkaran nedenlerden biri olarak karar vericilerin nitelikleri olduğu ileri sürülmüştür (Ryan, ve diğerleri, 2016). Bu çalışmada da katılımcıların cinsiyet ve yaşları ele alınmıştır. Ancak İngiltere'de üniversite öğrencileriyle yapılan bir çalışmada katılımcının cinsiyetinin, şirket performansına göre aday seçimini etkilemediği belirlenmiştir (Haslam \& Ryan, 2008). Amerika'da Kansas Üniversitesi’nde öğrenim gören 119 öğrenciyle yapılan başka bir araşturmada da cinsiyetin, cam uçurum olgusunu destekleyici karar alma üzerinde etkili olmadığı tespit edilmiştir (Bruckmüller \& Branscombe, 2010). Ancak cam uçurum olgusu kadınların aleyhine bir durum olduğu dikkate alındığında cam uçurum olgusunu destekleyici karar verme olasıllı̆ı üzerinde cinsiyetin bir etkiye sahip olduğu öngörülmektedir.

Sözü geçen araştırmalara göre aşağıdaki hipotezler oluşturulmuştur:

H1: Katılımcının cinsiyeti, cam uçurum olgusunu destekleyici karar alma olasılıklarını etkiler

H2: Katılımcının yaşı, cam uçurum olgusunu destekleyici karar alma olasılıklarını etkiler

Literatürde, bireylerin yönetici pozisyonuna ilişkin tercihleri ve cam uçurum olgusu arasındaki ilişkiye yönelik doğrudan veya dolaylı bir araştırmaya rastlanmadığından bu konuda aşağıdaki araştırma sorusu oluşturulmuştur:

Araştırma Sorusu: Katılımcıların ileride olmak istedikleri yönetici pozisyonuna ilişkin tercihleri cam uçurum olgusunu destekleyici karar alma olasılıklarını etkiler mi?

Araştırma kapsamında oluşturulan hipotezler ve araştırma sorusuna yönelik yapılan alan araştırmasına ilişkin bilgiler aşağıda açıklanmıştır.

\section{Araştırma Yöntemi ve Örneklem}

$\mathrm{Bu}$ araştırmada, toplumsal cinsiyet rollerinin bir yansıması olan cam uçurum olgusunun gençler tarafindan nasıl değerlendirildiğini tespit etmek amaçlanmışır. Gençlerin, ileride çalışma yaşamında söz sahibi olduklarında kadın yöneticilerin aleyhine bir durum olan cam uçurum olgusunu destekleyecek nitelikte bir karar alma olasılıklarını etkileyen faktörlerin belirlenmesine çalışılmıştır.

Günümüzde kadınların eğitim ve iş yaşamında erkekler kadar olmasa da geçmişe oranla daha fazla yer edinmesi, toplumsal cinsiyete dayalı rol paylaşımının etkisini azalttığını göstermektedir. Gençlerin, geçmişte yaygın olan söz konusu rol dağılımını benimsememesinin bu durum üzerinde etkili olduğu düşünülmüştür. Toplumsal cinsiyete dayalı rol paylaşımının ve bunun yansıması olan cam uçurum olgusunun kadınların aleyhine bir durum olması cinsiyetin bu durumda etkili olduğunu düşündürmektedir. Son olarak cam uçurum olgusunun yaşanması üst düzey yöneticilerin kadın yöneticilere yönelik olumsuz bir bakışından kaynaklandığından yönetici pozisyonunun da önemli bir faktör olabileceği öngörülmüştür. Dolayısıyla sözü geçen nedenlerden dolayı bireylerin, cam uçurum olgusunu destekler nitelikte karar alma olasılıkları üzerinde yaş, cinsiyet ve ileride olmak istedikleri yönetici pozisyonuna ilişkin tercihlerinin etkili olabileceği düşünülmüştür.

Araştırma kapsamında hazırlanan anket formunda katılımcılara finansal açıdan giderek zarar eden bir işletmede, bu işletmenin başına kadın bir yönetici mi yoksa erkek bir yönetici mi getirilmesi gerektiğine dair kararları sorulmuştur. 'Kadın yönetici' kararı cam uçurum olgusunu destekler nitelikte bir karar olarak; 'Erkek yönetici' kararı ise cam uçurum olgusunu desteklemeyen bir karar olarak değerlendirmeye alınmıştır.

Anket formunun bir diğer kısmında katılımcılara bir işletmede hangi konumda çalışmak istedikleri sorulmuş ve cevap olarak 'alt düzey çalışan', 'alt düzey yönetici', 'orta düzey yönetici' ve 'üst düzey yönetici' alternatifleri sunulmuştur.

Hazırlanan anket formu Şırnak Üniversitesi'nde 2019-2020 Eğitim-Öğretim döneminde aktif olarak öğrenim gören farklı bölümlerden öğrencilere uygulanmıştur. Toplanan anket formları incelenmiş olup, soruların cevapsız bırakıldığ örneklemler analiz dışı bırakılmıştır. Ayrıca verilerin ön incelemesinde 'bir işletmede hangi konumda çalş̧mak istersiniz?' sorusuna alt düzey çalışan cevabını veren 10; alt düzey yönetici cevabını veren sadece 3 kişi olduğu belirlenmiştir. Cam uçurum olgusu, yöneticilerin kararılla gerçekleştiğinden alt düzey çalışan olmak istediğini belirten 
Ece, S. (2020). Gençlerin, cam uçurum olgusunu destekleyici karar verme olasıllklarına yönelik bir ampirik araştırma. Journal of Human Sciences, 17(1), 304-314. doi:10.14687/jhs.v17i1.5943

katıllımcıların, cam uçurum olgusuna yönelik senaryoya ilişkin olarak tam bir cevap veremeyecekleri düşünülmüşs (kararsız seçeneği işaretleyenler bulunmakta), aynı zamanda az sayıda da olduklarından söz konusu örneklemler analiz dışı bırakılmışır. Alt düzey yönetici seçeneğini sadece 3 kişi işaretlediğinden bu örneklem de orta düzey yönetici grubuna dahil edilerek değerlendirmeye alınmıştır. Geriye kalan verilerle öğrencilerin cam uçurum olgusunu destekleyici karar verme olasıllkları üzerinde cinsiyet, yaş ve olmak istedikleri yönetici pozisyonuna ilişkin tercihlerinin etkisini ölçebilmek için Lojistik Regresyon Analizi yapılmıştır.

\subsection{Bulgular}

Lojistik Regresyon Analizi, iki kategoriden oluşan bağımlı değişken ile çoklu bağımsız değişkenler arasındaki ilişkiyi incelemek için uygulanmaktadır. Bu analizde, bireylerin hangi grubun üyesi olduğunu tahmin etmeye yardımcı olacak bir regresyon modeli oluşturulur. Kategorik ya da aralıklı ölçülen her bağımsız değişkenden biri referans olarak seçilir ve söz konusu değişkenin bağımlı değişken üzerindeki olasıllğı referans kategoriye göre değerlendirilir. Bu çalışmada, cinsiyet değişkeni iki kategoriden oluşmakta ve referans kategori olarak erkek; yönetici pozisyonuna ilişkin tercihte ise alt-orta düzey pozisyon referans olarak seçilmiştir. Yaş sürekli değişken olduğundan böyle bir seçim yapılamamıştır. Yapılan ilk analiz sonucunda Casewise List tablosunda ZResid değerleri çok yüksek olan $(3,6-4,4)$ olan örneklemler analiz dışı bırakılarak analizler tekrar yapılmıştur.

Değişkenlere ilişkin betimleyici istatistikler aşağıdaki tabloda gösterilmiştir:

Tablo 1. Tanımlayıcı İstatistikler

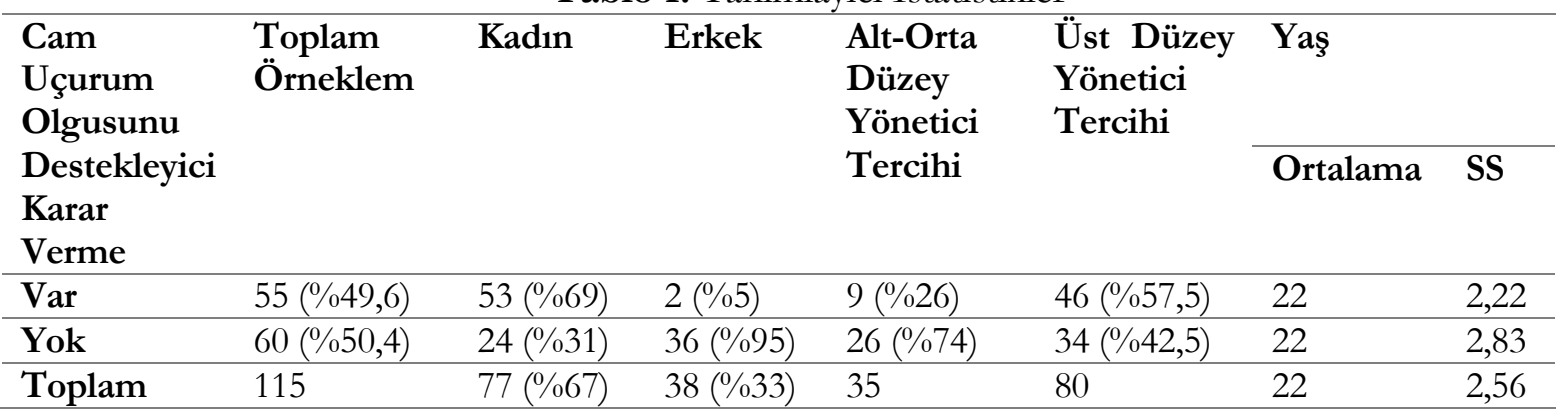

Araştırmaya katılan 115 öğrenciden 55’i cam uçurum olgusunu destekleyen bir durum olan işletmenin kötü zamanlarında işletmenin başına bir kadın yönetici getirilmesi gerektiği yönünde karar belirtirken; 60'1 ise böyle bir durumda bir erkek yöneticinin başa getirilmesi gerektiğini ifade ederek cam uçurum olgusunu desteklememiştir. Kendilerine sunulan senaryoya ilişkin verdikleri cevapla kadınların \%69'unun cam uçurum olgusunu destekledikleri; erkeklerin ise \%5'inin destekledikleri belirlenmiştir. Alt-orta düzey yönetici olmak istediğini belirten öğrencilerden \%26'sının senaryoya ilişkin verdikleri cevapla cam uçurum olgusunu destekledikleri; \% 074 'ünün ise desteklemediği ortaya çıkmıştır. Cam uçurum olgusunu destekleyici nitelikte karar veren öğrencilerin \%33'ünün ileride alt veya orta düzeyde bir yönetici olmak istediği; \%42,5'inin ise üst düzey yönetici olmak istediği belirlenmiştir. Cam uçurum olgusunu destekleyen ve desteklemeyen öğrencilerin yaş ortalamaları eşit olup 22 olarak tespit edilmiştir.

Bireylerin gruplara ait olma olasılıklarını belirlemeye ilişkin yapılan Lojistik Regresyon analizinde cinsiyet değişkeni için referans erkek olarak belirlenmiş; yönetici tercihi için ise referans grup alt-orta yönetim düzeyi olarak belirlenmiştir. Analiz sonuçları aşağıdaki tabloda gösterilmiştir: 
Ece, S. (2020). Gençlerin, cam uçurum olgusunu destekleyici karar verme olasıllklarına yönelik bir ampirik araştırma. Journal of Human Sciences, 17(1), 304-314. doi:10.14687/jhs.v17i1.5943

Tablo 2. Lojistik Regresyon Analiz Sonuçları

\begin{tabular}{|c|c|c|c|c|c|c|c|c|}
\hline \multirow{2}{*}{$\begin{array}{l}\text { Bağımsız } \\
\text { Değişkenler }\end{array}$} & \multirow{2}{*}{ B } & \multirow{2}{*}{ SE } & \multirow{2}{*}{ Wald } & \multirow{2}{*}{ df } & \multirow{2}{*}{$\mathrm{p}$} & \multirow{2}{*}{$\operatorname{Exp}(B)$} & \multicolumn{2}{|c|}{ \%95 Güven Aralığ1 } \\
\hline & & & & & & & Düşük & Yüksek \\
\hline Sabit & $-2,658$ & 2,386 & 1,241 & 1 & .265 & .070 & & \\
\hline Cinsiyet (1) & $-4,321$ & .838 & 26,569 & 1 & .000 & .013 & .003 & .069 \\
\hline Yaş & .098 & .108 & .827 & 1 & .363 & 1,103 & $.893-$ & 1,362 \\
\hline $\begin{array}{l}\text { Yönetici Pozisyonu } \\
\text { Tercihi (1) }\end{array}$ & 2,188 & .561 & 15,186 & 1 & .000 & 8,915 & 2,967 & 26,792 \\
\hline
\end{tabular}

Referans Grup kadın, alt-orta düzey pozisyonda yönetici olma tercihi

Tablodaki verilere göre erkeklerin, cam uçurum olgusunu destekleyici karar verme olasillğı, kadınlardan 0,013 kat daha düşüktür $(B=4,321 ; \mathrm{p}<0,01)$. Başka bir ifadeyle katılımcılar açısından bir kadının cam uçurum olgusunu destekleyici yönde karar alma olasılığı, bir erkeğe göre yaklaşık 77 kat $(1 / 0.013)$ daha yüksektir. Bu sonuca göre bireylerin cinsiyetleri, cam uçuruma yönelik kararlarını etkilemektedir. Dolayısıyla bu sonuçla H1 hipotezi desteklenmiştir. Cam uçurum olgusu, kadınların aleyhinde bir durum olduğundan kadın katılımciların, cam uçurum olgusunu destekleyici bir karar alma olasılıklarının, erkeklere göre daha düşük olduğu düşünülebilir. Ancak erkek çalışanlar tarafindan tercih edilmeyen, daha çok emek gerektiren ve getirisi az olabilen pozisyonlara kadın yöneticilerin getirilmesinin nedeni olarak kadınların, erkeklere göre iletişim, empati, ekip oluşturma gibi konularda daha yetenekli olması gösterilmiştir (Akbaş \& Taner, 2017). Bruckmüller ve Branscombe (2010)'ye göre kriz zamanlarında ihtiyaç duyulan stereotipik kadın özellikleri, sezgisel ya da başkalarının duygularının farkında olmak gibi kişilerarası nitelikleri içerdiğinden, böyle durumlarda kadınlar yönetici olara tercih edilebilmektedir.

Cam uçurum olgusunu destekleyici karar verme olasıllğı üzerinde yaş değisskeninin anlamlı bir etkisi bulunamamıştır $(B=.098 ; \mathrm{p}>0,05)$. Bu sonuçla $\mathrm{H} 2$ hipotezi desteklenmemiştir.

Bir işyerinde üst düzey yönetici olmak isteyen kattlımcıların cam uçurum olgusunu destekleyici karar verme olasıllı̆ı, alt-orta düzey yönetici olmak isteyen katılımcilardan 8,915 kat daha yüksektir $(B=2,188 ; p<0,05)$. Bu sonuca göre çalışma kapsamında oluşturulan araştırma sorusu 'Katılımcıların ileride olmak istedikleri yönetici pozisyonuna ilişkin tercihleri cam uçurum olgusunu destekleyici karar alma olasılıklarını etkiler' şeklinde cevaplandırılabilir.

Modelin genel değerlendirmesi aşağıdaki tabloda gösterilmiştir:

Tablo 3. Model Bilgileri

\begin{tabular}{llll}
\hline Testler & $\chi^{2}$ & SD (df) & p \\
\hline Wald Testi & 65,523 & 3 & .000 \\
\hline $\begin{array}{l}\text { Hosmer\&Lemeshow } \\
\text { Testi }\end{array}$ & 5,897 & 8 & .659 \\
\hline Cox\&Snell R ${ }^{2}$ & & & .434 \\
\hline Nagelkerke R \\
\hline
\end{tabular}

Bağımlı Değişken 0=Cam uçurum olgusu destekleme yok; 1=Cam uçurum olgusu destekleme var

Tabloda gösterilen veriler incelendiğinde, bağımsız değişkenlerin girildiği sonuç modelinin istatistiksel olarak anlamlı olduğu söylenebilir $\left(\chi^{2}=65,523 ; \mathrm{N}=115 ; \mathrm{df}=3 ; \mathrm{p}<0,01\right) . \mathrm{Bu}$ sonuçlara göre bireyin cam uçurum olgusunu destekleyici karar verme olasılığ1 üzerinde cinsiyeti ve olmak istediği yöneticilik pozisyonunun etkisi olduğu ifade edilebilir.

Hosmer\&Lemeshow testi gözlenen ve model tarafindan tahmin edilen olasilıkların (Tablo 4) uyumunu test etmektedir. Söz konusu test sonucunda hesaplanan 'p' değeri gözlenen ve model tarafından tahmin edilen değerler arasında anlamlı bir farkın olup olmadığını göstermektedir (Gürbüz \& Şahin, 2018). Tablo 3’teki değerlere göre Hosmer\&Lemeshow testi sonucu anlamsız çıkmıştır ( $\mathrm{p}>$.05). Bu sonuç, model tarafindan tahmin edilen değerler ile gözlenen değerler arasında 
Ece, S. (2020). Gençlerin, cam uçurum olgusunu destekleyici karar verme olasıllklarına yönelik bir ampirik araştırma. Journal of Human Sciences, 17(1), 304-314. doi:10.14687/ihs.v17i1.5943

anlamlı bir farkın olmadığını, başka bir ifadeyle modelin hesapladığı sınıflandırmanın, gerçek duruma yakın olduğunu göstermektedir.

Cox\&Snell $\mathrm{R}^{2}$ ve Nagelkerke $\mathrm{R}^{2}$ değerleri ise cam uçurum olgusunu destekleyici karar verme olasılığındaki varyansın yaklaşı \%43'ten \%58'e kadar olan kısmının bireyin cinsiyeti ve olmak istediği yöneticilik pozisyonu tarafindan açıklandığını göstermektedir. gösterilmiştir:

Lojistik Regresyon Analizi sonucundaki grupların sınıflandırılma oranlanı, aşağıdaki tabloda

Tablo 4. Sinıflandirma Oranı

\begin{tabular}{llll}
\hline \multirow{2}{*}{ Gözlenen } & \multicolumn{3}{c}{ Tahmin Edilen } \\
\cline { 2 - 4 } & $\begin{array}{l}\text { Cam Uçurum Olgusunu } \\
\text { Destekleyici Karar } \\
\text { Vermeyen }\end{array}$ & $\begin{array}{l}\text { Cam Uçurum Olgusunu } \\
\text { Destekleyici Karar } \\
\text { Vermeyen }\end{array}$ & $\begin{array}{l}\text { Doğruluk } \\
\text { Oranı }\end{array}$ \\
\hline $\begin{array}{l}\text { Cam Uçurum Olgusunu } \\
\text { Destekleyici Karar }\end{array}$ & 50 & 10 & $\% 83,3$ \\
$\begin{array}{l}\text { Vermeyen } \\
\begin{array}{l}\text { Cam Uçurum Olgusunu } \\
\text { Destekleyici Karar }\end{array}\end{array}$ & 10 & 45 & $\% 81,8$ \\
Veren & & & \\
\hline
\end{tabular}

Toplam Yüzde

$\% 82,6$

Yukarıdaki tabloya bakıldığında cam uçurum olgusunu destekleyici karar vermeyen 60 kişiden 10'u cam uçurum olgusunu destekleyen karar veren bireyler arasında gösterilmiştir. Cam uçurum olgusunu destekleyici karar vermeyen bireyler için doğru sınıflandırma oranı yaklaşık \%83 olarak hesaplanmıştur. Cam uçurum olgusunu destekleyici karar veren 55 kişiden 10'u cam uçurum olgusunu destekleyici karar vermeyen bireyler arasında gösterilmiştir. Buna göre cam uçurum olgusunu destekleyici karar alan bireyler için doğru sınıflandırma oranı yaklaşık \%81 olarak tespit edilmiştir. Toplam doğru sınıflandırma oranı ise \%82,6 olarak gerçekleşmiştir.

Sonuç olarak bir kadının ve üst düzey yönetici olmak isteyen bir kişinin cam uçurum olgusunu destekleyici karar alma olasıllğ̆, bir erkeğe ve alt-orta düzey yönetici olmak isteyen birine göre daha yüksektir.

\section{Sonuç}

Toplumsal cinsiyet rolleri nedeniyle kadınların iş yaşamına erişimi kısmen ya da tamamen engellenmiştir. $\mathrm{Bu}$ engelleri aşmayı başaran kadınlar çalışma yaşamında birtakım sorunlarla karşlaşabilmektedir. Bu sorunlardan biri cam uçurum olgusudur. Cam uçurum olgusu, iş yaşamında büyük emek harcayan, kendini geliştirerek elde ettiği başarılarla yönetici olmayı hak eden, ancak cam tavan sendromu nedeniyle yükselemeyen kadınların karşılaştı̆ı bir durumdur. İşletmenin ekonomik durumun kötüye gittiği, sorunların çokça yaşandığı vs. bir biriminde ya da genelinde riskli ve sorunları çok olan görevin başına getirilecek biri arandığında genellikle erkek çalışanlar geride dururlar. Cam tavan sendromu nedeniyle yükselemeyen başarılı kadın çalışanlar ise bu durumu kadınların da iyi bir yönetici olabileceğini kantlayabilecek bir firsat olarak görür. Üst düzey yöneticiler ise bir nevi enkaz devredecek kişi olarak kadın yöneticiyi seçme eğiliminde olur. Böylelikle sorunların çok olduğu bu görevde deyim yerindeyse ortalığı toparlayamadığında kadın yönetici başarısız olarak kabul edilir. Düşük te olsa böyle bir göreve getirilen kadın yöneticinin başarılı olma olasıllı̆̆ da vardır. Kadın yönetici başarılı olduğunda ise elde ettiği başarı onun yoğun çabasına değil, dış koşullara atfedilir. Bu değerlendirme sonucunda, harcadığ1 emeğin üst düzey yönetimde fark edilmediğini düşünen kadın yöneticinin motivasyonu düşer. Dolayısıyla her iki açıdan cam uçurumun kadın yöneticiye oldukça zarar verdiği söylenebilir. 
Ece, S. (2020). Gençlerin, cam uçurum olgusunu destekleyici karar verme olasılıklarına yönelik bir ampirik araştırma. Journal of Human Sciences, 17(1), 304-314. doi:10.14687/jhs.v17i1.5943

$\mathrm{Bu}$ çalışmada kadın yöneticileri yıpratan cam uçurum olgusu ele alınmışır. Gelecekte iş yaşamında yer alacak gençlerin cam uçurum olgusunu destekleyici yönde karar alma olasılıklarını etkileyen faktörler araşturlmıştır. Katılımcıların yaş, cinsiyet ve olmak istedikleri yönetici pozisyonu tercihi söz konusu faktörler arasında değerlendirilmiştir. Bu kapsamda Şırnak Üniversitesi'nde farklı bölümlerde öğrenim göre 115 öğrenciyle anket yapılmıştır. Öğrencilerin, cam uçurum olgusunu destekleyici karar verme olasıllkları üzerindeki cinsiyet, yaş ve yönetici pozisyonu tercihlerinin etkisini belirleyebilmek için Lojistik Regresyon Analizi yapılmıştır.

Analiz sonuçlanına göre cinsiyet ve yönetici pozisyonu tercihlerinin, cam uçurum olgusunu destekleyici karar verme olasılıkları üzerinde anlamlı bir etkisi olduğu, ancak yaşın anlamlı bir etkisinin olmadığı tespit edilmiştir. Araşturma kapsamında oluşturulan 'H1: Katılımcının cinsiyeti, cam uçurum olgusunu destekleyici karar alma olasılıklarını etkiler' hipotezi desteklenmiş; ancak 'H2: Katılımcının yaşı, cam uçurum olgusunu destekleyici karar alma olasılıklarını etkiler' hipotezi desteklenmemiştir. Analiz sonuçları, erkek katıllımcıların, cam uçurum olgusunu destekleyici karar alma olasılıklarının, kadın katılımcılara göre 0,013 kat daha düşük olduğunu göstermiştir $(B=4,321$; $\mathrm{p}<0,01)$. Bu sonuç, cinsiyetin, daha önce yapılan başka araştırmaları desteklememektedir (Haslam \& Ryan, 2008; Bruckmüller \& Branscombe, 2010). Bir işyerinde üst düzey yönetici olmak isteyen katılımcıların cam uçurum olgusunu destekleyici karar verme olasıllğı, alt-orta düzey yönetici olmak isteyen katılımcılardan 8,915 kat daha yüksektir $(B=2,188 ; \mathrm{p}<0,05)$. Bu sonuçla araştırma kapsamında oluşturulan 'Katulımcıların ileride olmak istedikleri yönetici pozisyonuna ilişkin tercihleri cam uçurum olgusunu destekleyici karar alma olasılıklarını etkiler mi?' sorusu 'Katılımcıların ileride olmak istedikleri yönetici pozisyonuna ilişkin tercihleri cam uçurum olgusunu destekleyici karar alma olasılıklarını etkiler' şeklinde cevap bulmuştur.

Cam uçurum olgusu, yüksek performans göstererek kurumun başarısına büyük katkıda bulunan kadın çalışanların örgütten koparak işten ayrılmalarına neden olabilmektedir (Sabharwal, 2013). Başarılı çalışanlarını kaybetmenin işletmeler üzerinde olumsuz etkileri olacağı şüphesizdir. Çünkü diğer çalışanlara oranla daha fazla emek harcayan, emekleri sonucunda işletmede işlerin daha iyi yürümesini sağlayan bir kadın çalısana üst düzey yönetim tarafindan cam uçurum olgusunun yaşatılması, diğer çalışanlar arasında yüksek performansın, üst düzey yönetim tarafindan karşıllı bulamadığı, aksine cezalandırıldığı algısını oluşturur. Bu algı sonucu, çalışanlar da performanslarını düşürme eğiliminde olur.

Bu çalışmada, kadın katılımcıların cam uçurum olgusunu destekler nitelikte karar alma olasılığının erkek katıllımcılara göre yüksek olması bir bakıma gelecekte iş yaşamında rol alacak gençler arasında kadınların, hemcinslerinin sorunları çözmesine dair inancını yansıttı̆ı söylenebilir. Üst düzey yöneticilerin de kadın çalışanlara deyim yerindeyse 'harcanabilir kalem' olarak değil de sorunların üstesinden gelebilecek yönetici aday olarak değerlendirmeleri önerilmektedir.

Üst düzey yönetici olmayı düşünen gençlerin cam uçurumu destekleyen karar alma olasılıklarının, alt-orta düzey yönetici olmak isteyenlere göre daha yüksek olması, üst yönetim tarafından sorumlulukların ve problemlerin çok olduğu görevlere kadın çalışanların getirilmesi eğiliminin gelecek nesilde de devam edebileceğini göstermektedir. Ancak günümüzden farklı olarak erkekler değil de kadınların, riskli görevlere kadın yöneticileri aday olarak gösterme eğiliminin daha fazla olması da dikkate alındığında bu durumun, kadınların sorunların üstesinden gelebileceğine dair inançtan kaynaklandığı söylenebilir. Nitekim bazı çalışmalar da kadınların iletişim, empati kurma, ekip oluşturma gibi birtakım özelliklerinden dolayı riskli görevlerin başına getirildiği ileri sürülmüştür (Akbaş \& Taner, 2017; Bruckmüller \& Branscombe, 2010).

Bu çalışma, günümüzde kadın yöneticilerinin karşılaşabildiği cam uçurum olgusunun, ileride taraflar açısından değişip değişmeyeceğine dair bir bilgi sunması açısından önem taşımaktadır. Ayrıca cam uçurum olgusunu destekleyici karar verme olasılıklarını araştıran çalışmalar da yok denecek kadar az olması göz önüne alındığında bu çalışmanı bu açıdan literatüre bir katkı sağlayacağ1 öngörülmektedir. Araştırma sonuçlarının iş dünyasındaki karar vericilere kadın yöneticileri ve sonrasında işletmenin genelini olumsuz yönde etkileyen cam uçurum olgusunun gelecek nesiller üzerindeki etkisi konusunda bir fikir vereceği düşünülmektedir. 
Ece, S. (2020). Gençlerin, cam uçurum olgusunu destekleyici karar verme olasıllklarına yönelik bir ampirik araştırma. Journal of Human Sciences, 17(1), 304-314. doi:10.14687/jhs.v17i1.5943

$\mathrm{Bu}$ çalışmanın sadece tek bir üniversiteden öğrencilerle yapılması kısıtlardan birini oluşturmaktadır. Ayrıca sadece nicel yöntem kullanılarak yapılması bir diğer kısıtını oluşturmaktadır. İleride bu araştırmanın başka bölgelerdeki üniversite öğrencileriyle de yapılarak cam uçurum olgusu üzerinde bölgenin bir etkiye sahip olup olmadığı belirlenebileceği düşünülmektedir. Başka araştırmalarda nicel yöntemin nitel yöntemlerden yarı yapılandırılmış görüşme ile desteklenerek katılımcılardan kararlarına yönelik daha fazla bilgi alınabileceği öngörülmektedir.

\section{Kaynaklar}

Akbaş, N., \& Taner, B. (2017). Yönetim ve Cinsiyet: Cam Uçurumun Ötesi. LAÜ Sosyal Bilimler Dergisi, 8(2), 193-214.

Ashby, J. S., Ryan, M. K., \& Haslam, S. A. (2006). Legal work and the glass cliff: Evidence that women are preferentially selected to lead problematic cases. $W m$. \& Mary J. Women \& $\mathrm{L}$.

Bechtoldt, M. N., Bannier, C. E., \& Rock, B. (2018). The glass cliff myth? - Evidence from Germany and the U.K. The Leadership Quarterly.

Bruckmüller, S., \& Branscombe. (2010). The glass cliff: When and why women are selected as leaders in crisis contexts. British Journal of Social Psychology, 49, 433-451.

Ece, S. (2019). Emekçi Kadmlar ve Cam Tavan Sendromu (2.Bask1 b.). Ankara: Gazi Kitabevi.

Gürbüz, S., \& Şahin, F. (2018). Sosyal Bilimlerde Araștrrma Yöntemleri: Felsefe-Yöntem-Analiz: Ankara: Seçkin Yayınevi.

Haslam, S. A., \& Ryan, M. K. (2008). The road tothe glass cliff: Differences in the perceived suitability of men and women for leadership positions in succeeding and failing organizations. The Leadership Quarterly, 19, 530-546.

Kulich, C., Lorenzi-Cioldi, F., Iacoviello, V., Fanikoa, K., \& Ryan, M. K. (2015). Signaling change during a crisis: Refining conditions for the glass cliff. Journal of Experimental Social Psychology, 96103.

Macarie, F., \& Moldovan, O. (2012). The ignored resource: Gender discrimination in the labor force. Managerial Challenges of the Contemporary, 4-12.

Mulcahy, M., \& Linehan, C. (2014). Females and Precarious Board Positions: Further Evidence of the Glass Cliff. British Journal of Management, 425-438.

Peterson, H. (2015). Is managing academics "women's work"? Exploring the glass cliff in higher education management. Educational Management Administration \& Leadership, 1-16.

Ryan, M. K., Haslam, S. A., Morgenroth, T., Rink, F., Stoker, J., \& Peters, K. (2016). Getting on top of the glass cliff: Reviewing a decade of evidence, explanations, and impact. The Leadership Quarterly, $27,446-455$.

Sabharwal, M. (2013). From Glass Ceiling to Glass Cliff: Women in Senior Executive Service. Journal of Public Administration Research and Theory, 25(2), 399-426.

Yıldız, S., Alhas, F., Sakal, Ö., \& Yıldız, H. (2016). Cam uçurum: Kadın yöneticiler cam tavanı ne zaman aşar? Ankara Üniversitesi SBF Dergisi, 71(4), 1119-1146.

\section{Introduction}

\section{Extended English Summary}

The desire of women to take part in business life was found to be contrary to the distribution of social roles, and for this reason, women who wanted to enter the business life encountered obstacles. In this study, the phenomenon of glass cliff, which is not as interesting as a glass ceiling, but hurts female managers as much as glass ceiling phenomenon is discussed.

\section{Glass Cliff Phenomenon}

The glass cliff points to the tendency to assign more female employees to risky positions within an organization than male employees (Ryan, et al., 2016). In enterprises where there is a glass cliff, male employees are reluctant to take these duties because they find these managerial duties risky and senior managers tend to give these tasks to female employees. Because even if the 
Ece, S. (2020). Gençlerin, cam uçurum olgusunu destekleyici karar verme olasıllklarına yönelik bir ampirik araştırma. Journal of Human Sciences, 17(1), 304-314. doi:10.14687/jhs.v17i1.5943

possible failure is due to the uncontrollable factors such as the nature of the job, the current conditions, etc., the female manager who is appointed by the senior managers is held responsible for this failure (Ece, 2019).

In a study, it was determined that the gender of the participant did not affect the selection of candidates according to company performance (Haslam \& Ryan, 2008). In another study conducted, it was found that gender was not effective on decision making to support the glass cliff phenomenon (Bruckmüller \& Branscombe, 2010).

According to the aforementioned studies, the following hypotheses and research question have been formed:

H1: The gender of the participant affects the decision making possibilities that support the glass cliff phenomenon

H2: Participant's age affects the decision making possibilities that support the glass cliff phenomenon

Research Question: Do the participants' preferences regarding the manager position they want to be in the future affect the probability of decision making that support the glass cliff phenomenon?

\section{Research Method and Sampling}

In this study, it was tried to determine the factors that affect the possibility of young people to make a decision that support the phenomenon of glass cliff, which is a reflection of the gender roles of the society. In the questionnaire form prepared within the scope of the research, the participants were asked about their decisions about whether a woman or a male manager should be appointed as the head of the enterprise that is increasingly damaging financially. As the "woman manager" decision supports the glass cliff phenomenon; The 'male manager' decision was considered as a decision that does not support the glass cliff phenomenon. The questionnaire prepared was applied to students from different departments in Şırnak University in the 2019-2020 academic year. Logistic Regression Analysis was conducted to measure the effect of students' preferences regarding gender, age and the managerial position they want to be, on the possibility of decision making that supports the glass cliff phenomenon.

\section{Findings}

While 55 of the 115 students who participated in the research made a decision that supports the glass cliff phenomenon by stating that a woman manager should be brought to the business during financial crisis times of the business; 60 of them did not support the glass cliff phenomenon by stating that a male manager should be brought to the head in such a situation.

As a result of logistic analysis, it has been determined that men are 0.013 times less likely to make decisions supporting the glass cliff phenomenon $(B=4,321 ; \mathrm{p}<0.01)$. In other words, a woman is approximately 77 times $(1 / 0.013)$ more likely to make a decision that support the glass cliff phenomenon than a man. According to this result, the gender of the individuals affect their decisions regarding the glass cliff. There was no significant effect of the age on the possibility of making decision supporting the glass cliff phenomenon $(B=.098 ; \mathrm{p}>0.05)$. Participants who want to become top managers in a workplace are 8.915 times more likely to make a decision that support the glass cliff phenomenon than those who want to become lower-mid level managers $(B=2.188$; $\mathrm{p}<0.05)$.

According to the general evaluation of the model, it can be said that the result model in which independent variables are entered is statistically significant $\left(\chi^{2}=65,523 ; \mathrm{N}=115 ; \mathrm{df}=3\right.$; $\mathrm{p}$ $<0.01)$. The results showed that the gender and the preference of managerial position have influence on the possibility of making decision that support the glass cliff phenomenon.

Cox \& Snell $\mathrm{R}^{2}$ and Nagelkerke $\mathrm{R}^{2}$ values show that approximately $43 \%$ to $58 \%$ of the variance in the probability of making a decision that support the glass cliff phenomenon is explained by the individual's gender and the preference of managrial position.

The correct classification rate for individuals who do not make a decision that support the glass cliff phenomenon is about $83 \%$; The correct classification rate for individuals who took the 
Ece, S. (2020). Gençlerin, cam uçurum olgusunu destekleyici karar verme olasılıklarına yönelik bir ampirik araştırma. Journal of Human Sciences, 17(1), 304-314. doi:10.14687/jhs.v17i1.5943

decision that support the glass cliff phenomenon was calculated as approximately $81 \%$. The total correct classification rate was calculated $82.6 \%$.

\section{Conclusion}

The phenomenon of glass cliff is a situation faced by women who spend great effort in business life, deserve to be managers with their successes, but who cannot rise due to glass ceiling syndrome. Successful women employees who cannot rise due to the glass ceiling syndrome see the glass cliff as an opportunity to prove that women can also be good managers. Senior executives tend to choose the female manager as a person to hand some sort of debris. Thus, in this task where there are many problems, the woman manager is considered to be unsuccessful when she is unable to recover the situation. Albeit low there is a possibility that the female manager, who has been appointed to such a position, is successful. When the woman manager is successful, her success is attributed to external conditions, not her intense effort. As a result of this evaluation, the motivation of the female manager, who thinks that the labor she spends is not noticed in the senior management, decreases. Therefore, from both angles, it can be said that the glass cliff caused a lot of damage to the female manager.

In this study, it was found that gender and managerial position preferences had a significant effect on the possibility of making decision that support the glass cliff phenomenon, but age did not have a significant effect. It can be said that female participants are more likely to make decisions that support the glass cliff phenomenon than male participants.

Given its adversely effect of glass cliff firstly women managers and then the overall business, it is thought that the results of the research will give the decision makers in the business world an idea about the impact of the glass cliff phenomenon on the next generation. 